\title{
Pedagogical Diagnosis and Self-learning in the Training of Foreign Language Teachers
}

\section{Diagnóstico pedagógico y autoaprendizaje en la formación de profesores de lenguas extranjeras}

\author{
DOI: $10.46932 / \mathrm{sfjdv2n5-058}$
}

Received in: Oct 1st, 2021

Accepted in: Dec 30th, 2021

\author{
Josué Bonilla Tenesaca \\ $\mathrm{PhD}$ in Pedagogical Sciences \\ Institution : Buckingham English Center \\ Personal adddress: Cdla. Matices Etapa Perla Mz 21 Villa 38, Ecuador \\ E-mail: josuedi7990@yahoo.co.uk / josue.bonillat1979@gmail.com
}

\author{
Isabel Batista Medina \\ $\mathrm{PhD}$ in Pedagogical Sciences \\ Institution : Universidad de Oriente \\ Personal adddress: Edificio C 18 Apto 4 Distrito José Martí, Santiago de Cuba, Cuba \\ E-mail: isabelb@uo.edu.cu / isabelbm56@ nauta.cu
}

Marisela Jiménez Alvarez

$\mathrm{PhD}$ in Pedagogical Sciences

Institution : Universidad de Oriente

Personal adddress: Edificio 18 Plantas Piso 10 Apto 01 Distrito José Martí Micro 9 Santiago de Cuba, Cuba

E-mail: jimenezmarisela09@gmail.com / mariselaj@uo.edu.cu

\begin{abstract}
SUMMARY
Universities in charge of training foreign language teachers have the responsibilities to guarantee and improve their preparation. In doing so, it is still evident that within Hispanic speaking environments, foreign language contexts require much attention. Hence, the pedagogical diagnosis allows describing, analyzing, interpreting, and comprehending the educative reality of future foreign language teachers, to design strategies for educative intervention. These strategies may facilitate personalized attention for enhancing self-learning and developing linguo-professional potentialities from classroom diversity. This paper has the aim of revealing the importance of pedagogical diagnosis for personal implication of the future foreign language teacher, his conscious responsibility in self-learning, as an active transformer of the reality. For the accomplishment of this task, several scientific methods such as analysis-synthesis, induction-deduction and hermeneutic were used.
\end{abstract}

Keywords: Pedagogical diagnosis, educative intervention, strategy, self-learning, teacher training.

\section{RESUMEN}

Las universidades encargadas de la formación de profesores de lenguas extranjeras tienen la responsabilidad de garantizar y mejorar su preparación. Para ello, sigue siendo evidente que, en los entornos hispanohablantes, los contextos de las lenguas extranjeras requieren mucha atención. Por ello, el 
diagnóstico pedagógico permite describir, analizar, interpretar y comprender la realidad educativa de los futuros profesores de lenguas extranjeras, para diseñar estrategias de intervención educativa. Estas estrategias pueden facilitar la atención personalizada para potenciar el autoaprendizaje y desarrollar las potencialidades lingüísticas-profesionales desde la diversidad del aula. Este trabajo tiene como objetivo revelar la importancia del diagnóstico pedagógico para la implicación personal del futuro profesor de lenguas extranjeras, su responsabilidad consciente en el autoaprendizaje, como transformador activo de la realidad. Para la realización de esta tarea se utilizaron varios métodos científicos como el análisissíntesis, la inducción-deducción y la hermenéutica.

Palabras clave: Diagnóstico pedagógico, intervención educativa, estrategia, autoaprendizaje, formación docente.

\section{INTRODUCTION}

At present, teachers' training constitutes a priority in the different teaching levels of Education in Cuba. The Third Educational Revolution strengthened by the Cuban State has undergone important educational changes to achieve an equitable society and a wide general integral culture, which permits facing the challenges of modern society.

Educational transformations will become effective if teachers working in the different teaching levels are professionally prepared to educate children, adolescents and youngsters, who will have in their hands the future development of the Cuban society.

In this sense, the university majors that are concerned with issues on Education are in charge of accomplishing this social responsibility of training pre-service trainees, in-service trainees and directives with solid scientific and pedagogical knowledge about methodological management that will enable them to develop their teaching tasks in each of the provinces, municipalities and school facilities.

Foreign Language Teaching Major has the mission to train future teachers with a pedagogical profile in correspondence with the demands of the Cuban society, by means of the harmonic, intensive development of linguistic, socio linguistic and sociocultural abilities, as well as, discursive strategies. These abilities will help the pre-service trainees express themselves orally and written about daily life topics that are present in the English language syllabuses of General Education.

The Cuban model for the professional training of foreign language teachers, demands the achievement of a B2 Common Reference Level in English, as well as an A2 for the achievement of a French communicative competence. This will enable them accomplishing their social tasks, taking into account the parameters stated by the Common European Frame of Reference for Languages (CEFR), as well as, a professional pedagogical competence. Nevertheless, this general goal requires a completely training system that will help them in achieving this goal. 
Common European Framework of References for Languages (CEFR) is a guideline for describing levels of achievement in language learning for foreign languages across Europe, including English, developed by the European organization of the Council of Europe. It describes six levels of achievement divided into three broad divisions, which describe what a learner should be able to do in reading, listening, speaking and writing.

It is intended to provide a common basis for describing communicative performance and to serve as a basis for developing language syllabuses, curriculum guidelines, examinations, and textbooks, regardless of the target language. It refers to the communicative competence, which comprises linguistic, psycholinguistic and sociolinguistic processes. So it implies the capacity to know what to say, to whom, when and how to say it.

Richards and Schmidt (2010), explain that communicative language teaching is an approach to foreign or second language teaching which emphasizes that the goal of language learning is communicative competence and which seeks to make meaningful communication and language use a focus of all classroom activities.

On the other hand, professional pedagogical communicative competence is understood, as the teacher's preparation that guarantees the successful development of professional tasks and functions. It should be in correspondence with the demands and particularities of participants and the familiar and communitarian contexts. (Parra \& Más, 2003)

Batista, (2001) underlines the concept above as "the capacity of the future teacher to perform efficiently his teaching task through an adequate use of knowledge and abilities for accomplishing the functions as stated in the professional model”. Batista, pág. 13

Limonta, et al (2017), add some other elements to this concept, expressing the use of methods and professional values towards the development of a humanistic personality, synthesized in a high didacticcommunicative pedagogical culture to solve professional problems within the educative contexts.

Nevertheless, some difficulties are still observed in the process of training foreign language teachers. Limonta, et al, (2017) refer in first place to the need of profiting more of the multiple advantages of pedagogical diagnosis and its role for getting the cyclical integration that should be attained since the design of objectives in each academic year. This difficulty has hindered the compilation of information about the cultural nature of the subjects and the learning integration to attain the professional pedagogical communicative competence of the teachers-to-be.

The authors mentioned above are calling for an integrated disciplinary work, to highlight the essential issues of content for the integration of different disciplines. Such foundations brake with the academic character of the subject, emphasizing on the need of inserting linguistic, sociocultural, 
philosophical, psycho-pedagogical, historical , and didactic aspects that must be learnt by future foreign language teachers.

The answer to these deficiencies requires the design of a pedagogical strategy that may improve the pedagogical diagnosis and propitiate formative learning. This paper has the aim of revealing the importance of pedagogical diagnosis for the personal growing of future foreign language teachers, their conscious responsibility in self-learning as an active transformer of the reality.

Pedagogical diagnosis may contribute to precise the various stages that future foreign language teachers undergo in their growth, their zone of proximal and long-term development, to recognize their professional improvement and to determine the progress achieved during their personality formation. It also presupposes conscious recognition of achievements and difficulties in the teaching learning process, in a way that may help to improve it.

\section{DEVELOPMENT}

The term diagnosis originated in the medical sphere. The Spanish Language Dictionary "Océano Multimedia", defines it as "A compound of signs that is used to fix the peculiar character of a disease". So the following formula could be stressed:

\section{dia $=$ through + gnosis $=$ knowledge}

"Diagnostics" (from the Greek lang. «diagnostikos» - a discerning, distinguishing) means "the ability to identify" (Aminov et al., 2002, p. 283). The term was first used in Ancient Greece medicine. For successful treatment, the Greeks tried to establish the cause of the disease, identify the characteristics of a sick organism, to collect information about the course of the disease, to determine the effect of various drugs, and due to the all symptoms, they properly made the diagnosis about sickness.

The Pedagogical Dictionary has also defined diagnosis: "the process of reflection that needs the analysis and concrete information". (pag.75). It presupposes the analysis of the students' learning and potentialities of their results.

Specialized literature recognizes as the essence of diagnosis, the systematic description and explanation of a given operative problem or situation. It also considers as its function to be a scientific procedure that helps to know the reality, make predictions, preview and guarantee success.

As a scientific activity, diagnosis has the aim of providing parameters for real educative interventions. Through its application one can, not only precise the problems, but also to find out the causes and possible solutions. 
As it could be seen, this definition now includes issues of pedagogical and psychological sciences. In the specialized literature, there are multiple definitions of diagnosis, which concentrate on pedagogical and psychological facts or on general features.

\section{WHAT DOES PEDAGOGICAL DIAGNOSIS CONSIST OF?}

Different authors as Brínguez (2010), Páez (1998), Recary Fernández. S (2003), Castellanos Simons. B (2004), Del Pino, J.L (1996), among others, consider pedagogical diagnosis as a continuous, dynamic, systemic and participative process that consists on describing, analyzing, interpreting and understanding the nature of the educative reality to express concrete judgments. In this sense, it also permits:

- To design, evaluate and modify teaching and learning strategies.

- To interpret the students' diversity and to provide an adequate individual treatment.

- To elaborate different learning tasks for measuring the students' ${ }^{\prime}$ development, potentiality and learning styles.

- To predict possible personal transformations.

Arias (2002), sustains, that pedagogical diagnosis should be organized using principles that give clarity for its further application:

- Individuality. Each person is unique.

- Multidisciplinary. Different approaches should be considered in correspondence with the school performance of the learner and under the base of different subjects.

- Continuous. It can be applied in different moments to evaluate the students's transformations.

- Scientific and objective. Scientific instruments are applied to compile concrete information about the students' bio-psychological-social reality.

The concepts and principles analyzed above allow the authors of this paper establishing the essential phases that typify the pedagogical diagnosis as an integrative, holistic process:

First phase: characterization of the phenomenon being researched, establishing the starting point or initial state.

Second phase: making prognostics of the tendencies of possible changes and previewing possible transformations.

Third phase: projecting actions that potentiate changes towards the desired state. (Final state)

Hence, teacher trainers who mentor future foreign language teachers must be prepared consciously, scientifically, objectively and efficiently, in order to apply pedagogical diagnosis through dimensions that spring from the careful analysis of the system of contents ; and in general in all the system 
of formation of a given major. That is to say, the different academic, scientific and labor components, which comprise the formation system.

In this sense, the pedagogical diagnosis provides parameters containing measurable and reliable indicators, which permit to evaluate the future foreign language teachers' pedagogical performance that contribute in the formation of their personality.

During the application of the pedagogical diagnosis, the teacher trainer uses a series of instruments that facilitate to get close to the educative reality of the teacher-to-be and later on make prognostics of his evolution. Specific and general instruments can be used according to the subjects' characteristics. Some of them are:

- Systematic, partial and final evaluations.

- Interviews

- Observations

- Documentary analysis

From the perspective of personalized teaching, all the information that is provided by the already mentioned instruments, ease the elaboration of pre-service trainees' profiles. Departing from this, it is possible to precise their strengths, potentialities and weaknesses which enable the design of strategies for pedagogical interventions, according to their educative needs and future decision making for curricular adjustments. Relevant physical, mental, linguistic, emotional, social developments are also analyzed, as well as family relationships, motivations, learning styles and learning strategies.

The information compiled from the instruments helps in deepening into the development of basic learning capacities, such as: perception, attention, memory, comprehension and reasoning during the initial developmental stage, and their real future potentialities, the image they have of themselves, selfesteem, respect for the others, and the capacity to receive and offer help.

\section{HOW IS PEDAgOGICAL DIAGNOSIS APPLIED IN THE TRAINING OF FOREIGN} LANGUAGE TEACHERS?

Pedagogical diagnosis in the training of ELFT major is a valuable tool for understanding, paying attention and giving solution to the multiple contradictions that take place in the diverse psychosocial classrooms of a university. To guarantee the personal implication of the future foreign language teacher and his conscious responsibility in self-learning, as an active transformer of the reality, pedagogical diagnosis must be structured as a process and as a result for contributing to the development of his professional pedagogical communicative competence. 
Then, the subject that benefits foremost the competence mentioned above is Integrated English Language Practice, which propitiates an active learning of the foreign language through the development of linguistic and professional abilities, learning styles and learning strategies.

The development of the English language communicative competence in the future teachers is a complex, pluri-motivated process, which uses diverse cognitive and metacognitive resources. For this reason, the subject Integrated English Language Practice (IELP) should propitiate an active learning, since the teachers-to-be do not learn at the same pace, nor develop their abilities in the same way, because they have different forms of learning. Therefore, they should be trained to use different language strategies for learning how to learn.

For the elaboration of the future teachers' profile, a sequence must be followed. In the first phase, the parameters embodied within the instruments should provide information about their strengths, potentialities and weaknesses. This preliminary information will allow the teacher trainers to ensure the effectiveness of the training and of the educational process in its scientific, methodological, organizational and practical aspects, through better planning and evaluating their self-learning during the training process.

Then, through the development of the (second phase), teacher trainers can make predictions concerning the tendencies of changes and possible transformations. Predictions are probable due to the information compiled in reference to the linguistic competence, that is, the phonological, lexical-semantic, discursive and pragmatic use of the foreign language.

Reflexive analysis derived from the application of the pedagogical diagnosis may induce concrete elements about the teaching learning process, specifically about the methods and procedures that could enhance motivation towards foreign language teaching within the pedagogical profession. The use of educational diagnostics helps to identify and quickly resolve deficiencies in the educational process, to predict the prospects of its development.

Some pedagogical experiences registered by the authors of this paper could precise some difficulties that still hinder the efficiency of the foreign language teaching training. For instance:

- Some linguistic abilities needed to be reinforced in some pre-service trainees, in order to develop a more efficient communicative competence. For instance, speaking, that is not highly developed due to insufficient language practice, health problems, and inadequate anatomical configuration of the organs of speech, among others.

- Cultural differences, depending on the pre-service trainees' home residency. Those who live in rural areas or have a low socio-economic development will need more pedagogical attention than those, who live in the cities, mainly in the use of the vocabulary.

- Unawareness of the differences and similarities between the native and foreign language. Those pre-service trainees that had a good command of the Spanish language learnt English easier. In contrast, with those who had deficiencies in the use of their mother tongue. They weren't able to 
make successful comparative analysis within the different levels of the linguistic analysis, which are essential for their future teaching practice in other educational levels.

- Incorrect combination of intrinsic motivation with extrinsic motivation. Their adequate combination has proven to be a powerful instrument that facilitated the accomplishment of the goals with the training of the future English language teachers.

- Need to incentive more autonomous learning with adequate teacher trainers' levels of help, in accordance with the successive results of the pedagogical diagnosis.

In general, experiences also denote the importance of deepening into the intrinsic and extrinsic motivation. They are both dynamic processes, which enhance self-esteem, sense of belonging for the profession and social commitment. In this way, the application of the pedagogical diagnosis during the second phase may encourage self-learning and the necessary metacognitive activity for the future foreign language teachers studying at the university.

Besides, the teacher trainers to secure the students' consciousness in getting adequate strategies that guarantee learning autonomy and self-regulation must implement levels of help. The strategies must also develop self-evaluation as a premise to improve cognitive independence and self-learning, which finally produce real transformations.

The application of the pedagogical diagnosis during the (third phase) permits projecting actions that potentiate changes towards the desired state. This is possible by means of external and observable didactic actions for each communicative activity. They are designed in correspondence to How they learn, stressing on the unity between teaching and learning, which implies several ways of teaching.

It is recommendable the use of the self-evaluation method (Batista, 2010), to feedback future foreign language teachers and to apply systematic diagnoses for adjusting their formative process. The application of this method provides the opportunity to demonstrate a clear oral and written expression and comprehension of the foreign languages, in correspondence with the parameters demanded by themselves and the subject.

The use of the self- evaluation method also permits learning self-direction to self-regulate their progress and to orient learning activities for intensifying content abilities and overcoming limitations.

Then, the following actions are recommended:

1- To appreciate success in terms of the teachers-to-be linguistic performance, through the Integrated English language Practice subjects, considering their objectives, system of knowledge and abilities, observing, analyzing and comparing their linguistic performance with the subject demands and verifying how far or near the results are achieved.

2- To interpret the results assuming the criteria from the Common European Frame of Reference for Languages (CEFR).

3- To learn how to listen to themselves while speaking and reading, as well as to take advantage of descriptive knowledge of the language: grammatical rules, phonetic transcriptions, morphological analysis, use of synonyms and antonyms, among others. 
4- To take into account conditions for their linguistic performance, weather representative or not, to enjoy the pleasure of communicative success.

5- To get information about the value of an error during foreign language learning, and also on behalf of teacher trainers' feedback.

6- To know how foreign language structures function within the communication system.

The application of the pedagogical diagnosis during the teaching training process produces a dynamics that activates conscious motives and self-regulation levels. The use of pedagogical diagnostics helps to identify and quickly resolve deficiencies in the educational process, to predict the prospects of its development.

Some other experiences registered by the authors of this paper, denote the importance of the future foreign language teachers' recognition of appropriate learning strategies in correspondence with learning styles. This advantage favors self-control of the communicative competence, which encourages cognitive resources and orients conscious reflections about how to build up self-learning and prepare them better for their future role as English language teachers.

\section{CONCLUSIONS}

Pedagogical diagnosis applied in the training of foreign language teachers at the universities constitute an important tool for teacher trainers and foreign language teachers-to-be to adjust either teaching or learning strategies; they are both set up as a dialectical unity in the formative process.

The personal implication of the future foreign language teachers is guaranteed through pedagogical diagnosis, by means of which profiles, predictions and strategic plans are elaborated looking for the benefits to improve qualitatively physical, psychosocial, linguistic and pedagogical perspectives during the teaching training process. 


\section{BIBLIOGRAPHY}

Aminov, M. et al. (2002) O`zbekiston milliy ensiklopediyasi. Gidrolofiya-Zebra. 3-tom. Toshkent.

Arias, B, G (2002): Educación, Desarrollo y Diagnóstico desde un enfoque Histórico Cultural. Edición Revolucionaria, Cuba.

Batista M. I (2010): Modelo didáctico alternativo del autoaprendizaje a través de la autoevaluación desarrolladora en el proceso de enseñanza-aprendizaje de la disciplina práctica integral de la lengua inglesa. Tesis doctoral. Cuba.

(2001): Estrategia evaluativa para fortalecer la dirección de la disciplina Práctica Integral (PILI) en la carrera Licenciatura en Educación de Lengua Inglesa en el ISP "Frank País García”. Tesis en la opción del título de Máster en Ciencias de la Educación. IPLAC.

Bermúdez, M. et al (2010): Aprendizaje formativo y crecimiento personal. Edición Revolucionaria, Cuba. Bringuez, S. (2010): El diagnóstico pedagógico. Una Herramienta de trabajo en la escuela. VI Taller Nacional de Comunicación Educativa.

Castellanos S. B. (2004): Esquema conceptual, referencial y operativo sobre la investigación educativa. Editorial Pueblo y Educación, Ciudad de La Castillo, M (2000): "El sobresaliente y la competencia comunicativa". Proyecto C.A.S. Colombia.Habana, 2005.

Castillo, M (2000): "El sobresaliente y la competencia comunicativa". Proyecto C.A.S. Colombia.

Council of Europe (2020), Common European Framework of Reference for Languages: Learning, teaching, assessment - Companion volume, Council of Europe Publishing, Strasbourg, available at www.coe.int/lang-cefr.

Cuellar, O (1987): La caracterización psicopedagógica: método para el estudio de la personalidad del alumno I. Editorial Pueblo y Educación. Cuba

Deci, E \& Ryan, R (2002): Handbook of self- determination research. Rochester University of Rochester Press.

-(2000): The what and why of goals pursuits: Human needs and self-determination of behavior. Rochester University of Rochester Press.

Del Pino, J. L.(1996 ) El Servicio de Orientación y Desarrollo: una contribución al desarrollo personal y profesional del estudiante. Editorial Pueblo y Educación. Cuba

Limonta, V. et al (2017): Proyecto de investigación "El diseño curricular de la formación inicial del licenciado en educación en lengua inglesa con segunda lengua”. UO. Cuba.

López, H (2000): Aprendizaje y desarrollo del escolar primario. Editorial Pueblo y Educación. Cuba.

Educación. Cuba

(1996): El Diagnóstico: un instrumento de trabajo pedagógico. Editorial Pueblo y

Recarey, Fernández, S. (2003) La función orientadora del maestro. Pueblo y Educación. Cuba. 
Richards, J and Schmidt,R (2010): Longman Dictionary of Language Teaching and Applied Linguistics. Pearson Education Limited.

Romeu, A. (et al), (2011): Didáctica de la lengua española y la literatura. Pueblo y Educación. Cuba. Picardo, O. (2005). Diccionario Enciclopédico de Ciencias de la Educación.

1ª Ed. - El Salvador, C.A.: Centro de Investigación Educativa, Colegio García Flamenco.

Parra, R \& Más, S. (2003): La Competencia Comunicativa Profesional Pedagógica. Una aproximación al estudio de su definición. monografías.com.

López, J (2003): El diagnóstico educacional para la atención a la diversidad. Ed. Pueblo y Educación. Habana.

López, J. et al. (s/f). Océano Multimedia de la Lengua Española. Círculo Digital. España.

González, A. (2000): Una Pedagogía de la Diversidad y la Equidad. Revista Varona. 